\title{
PENGEMBANGAN INSTRUMEN EVALUASI “SELF EVALUATION” DAN "PEER EVALUATION” LAYANAN KONSELING INDIVIDUAL DI SEKOLAH BAGI KONSELOR
}

\author{
${ }^{1}$ Muya Barida, M.Pd \\ ${ }^{2}$ Dr. Sutamo, M.Pd \\ ${ }^{12}$ Universitas Ahmad Dahlan, Yogyakarta \\ moza_barid@yahoo.com
}

\begin{abstract}
Individual counseling services in schools need to gain the attention of policymakers, among others, by the evaluation. The purpose of this research to produce products such as performance of counselors in individual counseling services instrument in schools both self evaluation and peer evaluation. This study uses a Research and Development Model. The steps of this study include: (1) Research and information collecting,(2) Planning, (3) Develop preliminary form of Product, (4) Preliminary field testing, (5) Main product revision, (6) Main field testing,(7) Operational product revision, (8) Operational field testing, and (9) Final product revision. The subjects of this research were junior high school counselors in Sukoharjo, junior high school counselor in Bantul and Expert of Guidance and Counseling. Early stages of product development gained 40 grains item instrument, later revised to 60 grains item. Further trials conducted end gained 57 grains of items for self evaluation and 57 grains of items for peer evaluation. The results of tests on a wider field gained 51 grains of items for self evaluation and 50 grains of items for peer evaluation.
\end{abstract}

Keyword: instrument evaluation, self-evaluation, peer evaluation, individualized counseling services in schools

Copyright (C) 2016 IICET (Padang - Indonesia) - All Rights Reserved Indonesian Institute for Counseling, Education and Theraphy(IICET)

\section{PENDAHULUAN}

Layanan konseling di sekolah diupayakan oleh guru bimbingan dan konseling atau konselor (Undang-undang No 20 Tahun 2003). Konselor menunjukkan kinerja professional dalam menyelenggarakan layanan konseling untuk memfasilitasi peserta didik mencapai perkembangan optimal baik dalam bidang pribadi, sosial, akademik, dan karier. ABKIN (2007: 189) menyebutkan bahwa peran konselor sebagai salah satu komponen student support services adalah men-support perkembangan aspek pribadi, sosial, karier, dan akademik siswa, melalui pengembangan menu program layanan bimbingan dan konseling kepada siswa dalam layanan dasar, layanan perencanaan individual, layanan responsif, dan dukungan sistem.

Menurut Morrison (2011) konselor melakukan fasilitasi kesuksesan akademik siswa, kemudian harus menjadi anggota pemecahan masalah dari sumber daya tim sekolah. Konselor harus mempunyai keterampilan untuk memberikan intervensi langsung maupun tidak langsung dalam merencanakan, mengarahkan, dan menerapkan program pencegahan, dan melayani sebagai advokat siswa. Konselor mempunyai peran dan fungsi yang jelas.

Kinerja konselor di sekolah salah satunya dalam layanan konsleing, masih perlu dievaluasi agar dapat dipahami secara integral dan komprehensif. Huda (2013) mengungkapkan bahwa masih ada konselor pada saat tahap perencanaan penyusunan program BK tanpa didahului kegiatan asesmen yang dijadikan bahan masukan bagi penyusunan program layanan, yaitu hanya menyalin program layanan BK sekolah lain, hasil pelatihan MGBK atau menggunakan program tahun sebelumnya dan tidak ada evaluasi program. Pada implementasi kegiatan layanan konseling individual, dilaksanakan hanya pada siswa bermasalah yang dikirim oleh guru mata pelajaran atau wali kelas, sedangkan konselor sekolah kurang aktif melakukan pendekatan dengan siswa. Selain itu, teknik yang digunakan masih konvensional, jarang yang kreatif menggunakan dan mengembangkan teknik-teknik pendekatan konseling individual. Konselor juga kurang maksimal dalam melakukan kolaborasi dengan orang tua, guru mata pelajaran, wali kelas, dan pihak terkait di lıar sekolah kurano maksimal 
Penelitian Kozlowski (2013) menyebutkan bahwa konselor sekolah hendaknya berkolaborasi dengan guru untuk mengintegrasikan kurikulum inti konseling, baik pada bidang akademik, pribadi-sosial, dan karier ke dalam pelajaran akademik siswa sehari-hari. Hal ini akan meningkatkan prestasi akademik bagi semua siswa dan menutup kesenjangan prestasi. Penelitian tersebut senada dengan Munro (2007) yang menyatakan bahwa guru dan konselor hendaknya bekerjasama untuk membantu siswa membuat pilihan-pilihan karier yang lebih realistis. Sherwood (2010) juga mengemukakan bahwa konselor perlu berkolaborasi dengan guru lain untuk memenuhi kebutuhan sekolah dan para siswa. Oleh karena itu, guru harus diberikan pemahaman umum tentang tujuan program konseling, peran dan tanggung jawab konselor (Joy, et al., 2011).

Sementara dalam kerjasama dengan pihak lain, Olguin \& Keim (2009) berpendapat bahwa pihak lain selaku stakeholder mampu menjadi jembatan karier bagi kemajuan performa akademik siswa. Konselor hendaknya membuat suatu perencanaan sehingga dapat memanfaatkan pihak lain dalam aktivitas perkembangan karier untuk memajukan kesuksesan akademik siswa. Selain kurang dalam kolaborasi, juga masih banyak dijumpai di lapangan bahwa kinerja konselor sekolah lebih untuk memenuhi tuntutan formal daripada memenuhi kebutuhan siswa. Konselor merasa sudah bekerja bila sudah memenuhi tuntutan formal yang berupa tugas-tugas administrasi seperti pengumpulan dan pengisian data dalam berbagai format. Tugas administrasi yang sebenarnya merupakan kegiatan pendukung untuk dapat melakukan layanan dengan baik, dianggap sebagai tugas utama.

Aspek dari layanan konseling individual masih perlu ditelusuri untuk dievaluasi lebih lanjut. Oleh karena itu, sesuai dengan latar belakang di atas peneliti ingin mengembangkan instrumen evaluasi layanan konseling individual di sekolah yang dapat digunakan oleh konselor sendiri (self evaluation) dan pihak lain yang berkepentingan (peer evaluation).

Layanan konseling individual merupakan unjuk kerja konselor dalam menyelenggarakan hubungan profesional dengan individu konseli untuk mencapai tujuan perkembangan yang lebih optimal. Upaya untuk menetapkan tujuan pelaksanaan konseling terlihat mudah, namun cukup rumit. Geldard \& Geldard (2012: 4) mengidentifikasikan tujuan konseling, yaitu tujuan dasar, tujuan orangtua, tujuan konselor, dan tujuan anak/siswa. Tujuan layanan konseling tidak kaku, tergantung pada suatu kebutuhan tertentu. Dapat disimpulkan bahwa tujuan dari konseling antara lain: (a) konseli atau siswa mampu memahami dirinya, potensinya, kelebihan, dan kelemahan, serta lingkungannya; (b) konseli atau siswa mampu menyesuaikan dirinya, potensinya, kelebihan, dan kelemahannya sesuai perubahan atau kebutuhan perkembangan lingkungan; (c) konseli atau siswa mampu mengarahkan dirinya, potensi, dan kelebihannya terhadap hal-hal yang produktif; (d) konseli atau siswa mampu mengembangkan dirinya, potensi, dan kelebihannya terhadap pencapaian yang lebih optimal; dan (e) konseli atau siswa mampu memperbaiki atau mengatasi kelemahannya sehingga mampu mencapai keadaan yang baik dan positif.

Upaya untuk mencapai berbagai tujuan di atas, dilakukan oleh konselor melalui pendekatan konseling dalam layanan konseling. Beberapa pendekatan konseling yang sering digunakan oleh konselor dalam pelaksanaan konseling antara lain: (1) Humanistik; (2) Behavioristik; (3) Cognitive-Behavioral; (4) Rational Emotive Behavioral; dan (5) Reality (Corey, 2009).

Salah satu kompetensi konselor profesional bahwa konselor menyelenggarakan layanan bimbingan dan konseling yang memandirikan. Dalam hal ini, konselor menyelenggarakan layanan konseling individual yang memandirikan. Pemikiran tentang kinerja konselor dalam layanan konseling individual tersebut didasarkan bahwa konselor harus menyelenggarakan layanan konseling individual yang memandirikan siswa. Secara khusus, kinerja konselor dalam layanan konseling individual dengan mengacu pada kerangka sosok utuh kompetensi konselor (ABKIN, 2007) antara lain dapat diuraikan menjadi: (1) Perencanaan layanan konseling individual, yang mencakup: (a) Menganalisis kebutuhan siswa terhadap layanan konseling individual, dan (b) Menyusun rencana layanan konseling individual yang berkelanjutan berdasar kebutuhan siswa secara komprehensif dengan pendekatan perkembangan; (2) Pelaksanaan layanan konseling individual, yang mencakup: (a) Melaksanakan rencana layanan konseling individual, (b) Melaksanakan pendekatan kolaboratif dalam layanan konseling individual, (c) Memfasilitasi perkembangan pribadi, sosial, akademik, dan karier siswa, dan (d) Mengelola sarana rencana layanan konseling individual; serta (3) Evaluasi layanan konseling individual, yang mencakup: (a) Melakukan evaluasi proses, dan (b) Evaluasi hasil layanan konseling individual.

Berdasarkan berbagai pendapat di atas, dapat disimpulkan bahwa kinerja konselor dalam layanan konseling di sekolah adalah unjuk kerja konselor dalam menyelenggarakan hubungan profesional dengan individu konseli untuk mencapai tujuan perkembangan yang lebih optimal, yang mencakup tahap: (a) Perencanaan layanan konseling individual, (b) Pelaksanaan layanan konseling individual, dan (c) Evaluasi layanan konseling individual.

Hadjar (1996) mengungkapkan bahwa instrumen merupakan suatu alat ukur yang digunakan untuk memperoleh informasi secara objektif tentang karakteristik variabel yang bervariasi objektif. Hal ini berarti bahwa instrumen digunakan untuk menggali suatu data atau informasi tentang suatu objek yang diinginkan peneliti secara objektif. 
Lebih lanjut, Suryabrata (2008) juga berpendapat bahwa instrumen merupakan suatu alat yang digunakan untuk merekam keadaan dan aktivitas atribut-atribut psikologis yang pada umumnya secara kuantitatif. Atribut-atribut psikologis secara teknis dapat diklasifikasikan menjadi dua, yaitu atribut kognitif dan atribut non-kognitif. Stimulus dari atribut kognitif berupa pertanyaan, sedangkan stimulus dari atribut non-kognitif berupa pernyataan.

Suharsimi (2010) menjelaskan bahwa instrumen merupakan suatu alat bantu yang dipilih dan digunakan oleh peneliti dalam melaksanakan kegiatan untuk mengumpulkan data, agar kegiatan tersebut dapat tersusun sistematis dan menjadi lebih mudah. Melalui instrumen, peneliti mampu mengatur kegiatan penelitian secara sistematis dan terencana.

Berdasarkan beberapa pendapat ahli di atas, dapat disimpulkan bahwa instrumen merupakan alat yang digunakan peneliti untuk mengungkap aspek yang ingin diungkap. Secara umum, instrumen dapat dibedakan menjadi dua jenis yaitu instrumen tes dan instrumen non-tes. Penelitian ini menggunakan instrumen non-tes. Menurut Asep (2007), non-tes merupakan prosedur penilaian untuk memperoleh suatu gambaran mengenai karakteristik sifat, minat, atau kepribadian individu. Instrumen non-tes yang biasa digunakan dalam bimbingan dan konseling terdiri dari beberapa jenis, antara lain observasi, wawancara, studi dokumentasi, sosiometri, angket atau kuesioner, dan inventori.

Inventori merupakan instumen yang digunakan untuk mengukur suatu karakteristik psikologis dari individu. Chaplin (2006: 260) berpendapat bahwa inventori merupakan suatu alat yang digunakan untuk menaksir atau menilai ada atau tidaknya tingkah laku, minat, sikap tertentu dan sebagainya yang biasanya berbentuk daftar pernyataan atau pertanyaan yang harus dijawab. Selanjutnya, Rahardjo dan Gudnanto (2013: 68) menyampaikan bahwa jenis data inventori yang dapat dikumpulkan meliputi temperamen, karakter, penyesuaian diri, sikap, minat, kebiasaan belajar, gambaran diri, jenis masalah, inventori tugas perkembangan, ungkap masalah, dan sebagainya. Berdasarkan kedua pendapat tersebut, dapat disimpulkan bahwa melalui daftar pernyataan yang dijawab oleh responden, maka dapat diketahui kemungkinan tingkah laku, minat, sikap, atau aspek psikologis tertentu sesuai dengan tujuan peneliti.

Istilah evaluasi dalam masyarakat umum biasa disebut dengan penilaian. Individu melakukan evaluasi terhadap suatu objek, dapat dikatakan bahwa individu sedang melakukan penilaian terhadap objek tersebut. Dalam penelitian ini, evaluasi dimaksudkan terhadap kinerja konselor dalam layanan konseling individual di sekolah.

Wrightstone, dkk. (dalam Umar, 2002) mengemukakan bahwa evaluasi merupakan suatu penaksiran terhadap pertumbuhan dan kemajuan pada arah tujuan atau nilai yang ditetapkan. Sebelum melakukan evaluasi, peneliti harus menetapkan tujuan atau fungsi dari kegiatan evaluasi. Selanjutnya Tague-Sutclife (1996: 1-3) menyatakan bahwa evaluasi adalah serangkaian proses yang sistematis untuk menentukan tingkat sejauhmana tujuan yang telah ditetapkan dapat dicapai oleh individu. Hal ini dapat disimpulkan bahwa individu yang melakukan kegiatan evaluasi melakukan perencanaan dan pelaksanaan secara terstruktur dan terencana.

Pendapat di atas sesuai dengan penjelasan Djaali dan Pudji (2008: 1) bahwa evaluasi merupakan suatu proses untuk menilai suatu objek berdasarkan pada kriteria atau tujuan yang telah ditetapkan sebelumnya kemudian diikuti dengan pengambilan keputusan terhadap objek yang diievaluasi. Melalui hasil evaluasi terhadap suatu objek, maka dapat dilakukan perlakuan tertentu sesuai tujuan peneliti.

Evaluasi sangat diperlukan untuk mengetahui upaya konselor dalam merencanakan, melaksanakan, serta mengevaluasi layanan konseling individual yang telah diselenggarakan kepada konseli atau siswa. Berdasarkan pendapat yang telah dikemukakan pada bagian sebelumnya, dapat dikatakan bahwa evaluasi mempunyai tujuan tertentu.

Suharsimi dan Jabar (2008: 2) menyampaikan bahwa evaluasi merupakan kegiatan dalam rangka mengumpulkan informasi tentang bekerjanya sesuatu, yang selanjutnya informasi tersebut digunakan untuk menentukan alternatif pilihan yang tepat dalam mengambil suatu keputusan. Hal ini merupakan dasar bagi peneliti untuk mengembangkan instrumen evaluasi layanan konseling individual di sekolah yang dapat digunakan dalam praktik layanan bimbingan dan konseling di sekolah.

Berdasarkan konsep yang telah dijelaskan pada bagian sebelumnya, dapat diuraikan bahwa instrumen evaluasi merupakan alat yang digunakan peneliti untuk mengetahui kinerja konselor dalam layanan konseling individual di sekolah. Instrumen evaluasi diharapkan dapat menjadi alat yang valid untuk mengungkap aspek kinerja konselor dalam layanan konseling individual di sekolah secara integral dan komprehensif yang meliputi (a) Perencanaan layanan konseling individual, (b) Pelaksanaan layanan konseling individual, dan (c) Evaluasi layanan konseling individual.

Aspek merencanakan layanan konseling, meliputi: 1) Meganalisis kebutuhan siswa terhadap layanan konseling, 2) Menyusun rencana layanan konseling yang berkelanjutan berdasar kebutuhan siswa secara komprehensif dengan pendekatan perkembangan. Aspek melaksanakan layanan konseling, meliputi: 1) Melaksanakan rencana layanan konseling, 2) Menggunakan pendekatan kolaboratif dalam layanan konseling, 3) Memfasilitasi perkembangan pribadi, sosial, akademik, dan karir siswa melalui layanan konseling, dan 4) Mengelola sarana dalam melaksanakan layanan konseling. Aspek mengevaluasi layanan konseling, meliputi: 
1) Melakukan evaluasi proses layanan konseling, 2) Melakukan evaluasi hasil layanan konseling, dan 3) Menulis laporan.

\section{METODELOGI PENELITIAN}

Penelitian ini menggunakan Model Penelitian Research and Development (R\&D). Menurut Borg \& Gall (1989: 782), R\&D merupakan proses yang digunakan untuk mengembangkan dan memvalidasi suatu produk. Langkah-langkah proses ini biasanya disebut sebagai siklus $\mathrm{R} \& \mathrm{D}$, yang terdiri dari mempelajari hasil penelitian yang berkaitan dengan produk yang akan dikembangkan, mengembangkan produk berdasarkan penemuan di lapangan, mengujicobakan di lapangan di mana produk akan digunakan akhirnya, dan merevisinya untuk memperbaiki kekurangan yang ditemukan dalam uji coba di lapangan yang menunjukkan bahwa produk tersebut memenuhi tujuan perilaku yang didefinisikan atau sesuai dengan produk yang akan dikembangkan. Jadi, tujuannya adalah meningkatkan kualitas hasil penelitian sebelumnya dan menemukan hal-hal yang baru di luar hasil dari penelitian itu.

Lebih lanjut, Sugiyono (2010: 407) menjelaskan bahwa R\&D merupakan metode penelitian yang digunakan untuk menghasilkan suatu produk dan menguji keefektifan produk tersebut. Produk dapat dihasilkan dengan melakukan analisis kebutuhan terhadap produk yang akan dikembangkan. Sementara produk tersebut akan diuji keefektifannya pada lapangan terbatas sebelum digunakan pada sasaran yang lebih luas.

\section{Prosedur Penelitian}

Adapun prosedur penelitian R\&D menurut Borg and Gall (1983: 775) meliputi: (1) Research and information collecting atau penelitian dan pengumpulan data,(2) Planning atau perencanaan, (3) Develop preliminary form of Product atau pengembangan produk awal, (4) Preliminary field testing atau uji coba awal, (5) Main product revision atau revisi produk, (6) Main field testing atau uji coba akhir,(7) Operational product revision atau revisi produk operasional, (8) Operational field testing atau uji coba pada lapangan yang lebih luas, (9) Final product revision atau revisi produk akhir, dan (10) Dissemination and implementation atau diseminasi dan implementasi. Peneliti tidak sampai melakukan tahap ini karena keterbatasan waktu dan biaya.

\section{Uji Coba Produk}

Subjek coba penelitian dalam penelitian ini antara lain ahli Bimbingan dan Konseling, konselor SMP di Kota Sukoharjo, dan konselor SMP di Kota Bantul. Bagi Ahli Bimbingan dan Konseling akan menggunakan serangkaian pernyataan verbal yang mengukur aspek-aspek kinerja konselor dalam layanan konseling individual di sekolah, ketepatan, kelayakan, kebermanfaatan, keterbacaan serta tata tulis instrumen. Sementara bagi konselor sekolah, peneliti menggunakan serangkaian pernyataan verbal yang menunjukkan aspek-aspek kinerja konselor dalam layanan konseling individual di sekolah. Desain uji coba berbentuk instrumen inventori evaluasi layanan konseling individual di sekolah. Peneliti melakukan uji validitas dan reliablitas instrumen inventori kepada ahli bimbingan dan konseling menggunakan instrumen angket.

Prosedur penyusunan instrumen (dalam hal ini inventori) menurut Iskandar (2008: 79) mulai dari tahap perencanaan, yang digunakan sebagai instrumen dalam penelitian ini terdiri dari langkah-langkah: 1) Menjelaskan definisi konseptual, yaitu peneliti menggali konsep dasar dari variabel layanan konseling individual di sekolah dari pendapat para ahli; 2) Menjelaskan definisi operasional, yaitu peneliti mendefinisikan variabel layanan konseling individual di sekolah berdasarkan definisi konseptual yang dikemukakan oleh para ahli; 3) Menentukan dimensi atau aspek-aspek, yaitu peneliti menguraikan aspekaspek variabel layanan konseling individual di sekolah; 4) Menentukan indikator, yaitu peneliti menjabarkan aspek variabel layanan konseling individual di sekolah; 5) Menentukan nomor item, yaitu peneliti mendistribusikan indikator dalam bentuk item-item pernyataan dalam instrument; 6) Menuliskan kisi-kisi item pernyataan, yaitu peneliti mendeskripsikan kisi-kisi item pernyataan; 7) Uji coba skala nilai, yaitu peneliti melakukan uji validitas dan reliabilitas instrumen kepada subjek uji coba; dan 8) Skorring, yaitu peneliti memberikan skor pada hasil pengisian instrumen. Skor yang diperoleh dari uji coba skala nilai perlu dianalisis untuk menguji validitas dan reliabilitas skala nilai.

Analisis data uji coba instrumen evaluasi layanan konseling individual di sekolah menggunakan Rumus Cronbach's Alpha. Tujuan dari analisis cronbach's alpha ini adalah memilih item yang reliabel dengan nilai cronbach's alpha diatas $0,5(\geq 0,5)$ dan butir item yang valid dengan koefisien lebih besar dari $0,3$ ( $\geq 0,3)$ (Atmoko, 2012). Peneliti menggunakan bantuan program SPSS 16.0 for Windows untuk melakukan analisis dengan teknik analisis ini.

\section{HASIL DAN PEMBAHASAN PENELITIAN Penelitian dan Pengumpulan Data}

Peneliti telah melakukan studi pendahuluan untuk mengetahui kebutuhan di lapangan terhadap perlunya pengembangan instrumen layanan konseling individual bagi konselor sekolah. Instrumen yang diperlukan dapat digunakan untuk self evaluation maupun peer evaluation. 


\section{Perencanaan}

Peneliti menentukan bahwa: 1) Tujuan penggunaan produk yaitu agar konselor sekolah dapat melakukan self evaluation maupun peer evaluation layanan konseling individual, 2) Pengguna produk yaitu konselor sekolah baik bagi diri sendiri maupun rekan kerja konselor sekolah, dan 3) Komponen produk berupa kuesioner layanan konseling individual yang mencakup aspek perencanaan, pelaksanaan, dan evaluasi layanan konseling individual.

\section{Pengembangan Produk Awal}

Berdasarkan ketiga aspek layanan konseling individual, peneliti menguraikan indikator, deskriptor, serta nomor item dari setiap deskriptor. Item yang dikembangkan sebanyak 40 butir.

\section{Uji Coba Awal}

Uji coba awal dilakukan expert judgement. Peneliti meminta bantuan kepada pakar layanan bimbingan dan konseling, yaitu Dr. Wagimin, M.Pd dari Universitas Ahmad Dahlan dan Drs. Syamsudin, SU., Kons. dari Universitas Ahmad Dahlan. Hasil ujicoba dapat diperoleh skor sebagai berikut: 1) Dr. Wagimin, M.Pd memberikan penilaian untuk aspek ketepatan yaitu Sangat Setuju (skor = 5), aspek kelayakan yaitu Sangat Setuju (skor = 5), dan aspek kebermanfaatan yaitu Sangat Setuju (skor = 5); dan 2) Drs. Syamsudin, SU., Kons. memberikan penilaian untuk aspek ketepatan yaitu Setuju (skor = 4), aspek kelayakan yaitu Setuju (skor =4), dan aspek kebermanfaatan yaitu Setuju (skor $=4$ ). Hasil uji coba kepada dua ahli dapat disimpulkan bahwa instrument tepat, layak, dan bermanfaat untuk mengetahui kinerja konselor dalam layanan konseling individual di sekolah.

\section{Revisi Produk}

Berdasarkan penilaian dan saran yang diberikan oleh ahli, maka peneliti melakukan revisi instrumen. Adapun yang diperbaiki dalam kisi-kisi instrumen yaitu menambahkan deskriptor dalam aspek merencanakan layanan konseling, melaksanakan layanan konseling, maupun dalam aspek mengevaluasi layanan konseling. Sehingga awalnya item instrumen yang berjumlah 40 butir menjadi 60 butir. Selain itu, alternative jawaban dalam instrument berubah dari lima skala yaitu Sangat Sesuai (SS), Sesuai (S), Agak Sesuai (AS), Tidak Sesuai (TS), dan Sangat Tidak Sesuai (STS) menjadi tiga skala yaitu Selalu (S), Kadang-kadang (K), dan Tidak Pernah (T).

\section{Uji Coba Akhir}

Peneliti melakukan uji coba kepada sepuluh konselor yang tersebar di beberapa sekolah di Kabupaten Sukoharjo. Setelah melakukan uji coba, peneliti melakukan analisis data menggunakan Rumus Cronbach's Alpha dengan bantuan SPSS 16 for windows. Hasilnya sebagai berikut.

\section{Uji Coba Akhir Instrumen Self-Evaluation}

Analisis Pertama, hasil perhitungan reliabilitas instrumen menggunakan rumus cronbach's alpha, diperoleh koefisien sebesar 0,931 $(\geq 0,5)$. Koefisien ini termasuk dalam kategori reliabilitas tinggi, tetapi perlu diperhatikan validitas butir yang terkandung dalam instrumen. Oleh karena itu, perlu dilihat koefisien nilai dalam tabel item-total statistics pada kolom corrected item-total correlation. Butir item yang memiliki nilai corrected butir-total correlation di atas $0,3(\geq 0,3)$ adalah valid. Sementara item yang mendekati 0,3 akan dipertahankan, karena ada kemungkinan korelasinya akan meningkat setelah dilakukan analisis uji ulang. Dikhawatirkan terlalu banyak butir soal yang harus dibuang/hilang, maka sebaiknya dicoba terlebih dahulu dengan mengeluarkan butir soal yang memiliki koefisien corrected item-total correlation pada rentang $-0, \ldots$ sampai 0,200. Berdasarkan hasil uji validitas diperoleh 14 item dengan koefisien di bawah 0,3 yaitu nomor 8, $9,23,24,25,31,34,45,46,48,49,50,51$, dan 55. Peneliti akan melakukan uji ulang, sehingga terlebih dahulu mengeluarkan nomor 9, 23, 24, 25, 31, 34, dan 45.

Analisis Kedua, hasil uji ulang dengan menggugurkan 7 butir item yang tidak valid, terjadi peningkatan koefisien reliabilitas cronbach's alpha dari 0,931 menjadi 0,959 dengan mengurangi butir item dari 60 menjadi 53. Selanjutnya digugurkan item nomor 46, 50, dan 51.

Analisis Ketiga, hasil uji ulang dengan menggugurkan 3 butir item yang tidak valid, ternyata juga terjadi peningkatan koefisien reliabilitas cronbach's alpha dari 0,959 menjadi 0,964 dengan mengurangi butir item dari 53 menjadi 50. Selanjutnya digugurkan item nomor 48 dan 49.

Analisis Keempat, hasil uji ulang dengan menggugurkan 2 butir item yang tidak valid, ternyata juga terjadi peningkatan koefisien reliabilitas cronbach's alpha dari 0,964 menjadi 0,966 dengan mengurangi butir item dari 50 menjadi 48. Selanjutnya digugurkan item nomor 8 dan 55.

Analisis Kelima, hasil uji ulang dengan menggugurkan 2 butir item yang tidak valid, ternyata juga terjadi peningkatan koefisien reliabilitas cronbach's alpha dari 0,966 menjadi 0,969 dengan mengurangi butir item dari 48 menjadi 46. Pada tabel Corrected Item-Total Correlation, seluruh butir telah memiliki koefisien korelasi butir terhadap total yang sama atau lebih besar dari 0,3. Artinya seluruh butir telah memberikan sumbangan terhadap totalnya $\geq 30 \%$. Setelah diperoleh 46 butir yang memiliki sumbangan $\geq 30 \%$ terhadap skor total, maka tahap berikutnya adalah merevisi instrumen. 


\section{Uji Coba Akhir Instrumen Peer-Evaluation}

Analisis Pertama, hasil perhitungan reliabilitas instrumen menggunakan rumus cronbach's alpha (table 5.2), diperoleh koefisien sebesar 0,848 ( $\geq 0,5)$. Koefisien ini termasuk dalam kategori reliabilitas tinggi, tetapi perlu diperhatikan validitas butir yang terkandung dalam instrumen. Berdasarkan hasil uji validitas diperoleh 13 item dengan koefisien di bawah 0,3 yaitu nomor 5, 8, 15, 23, 24, 25, 26, 27, 31, 34, 37, 43, dan 45. Peneliti akan melakukan uji ulang, sehingga terlebih dahulu mengeluarkan nomor 15, 23, 24, 25, 26, 27 , 31, 34, dan 37.

Analisis Kedua, hasil uji ulang dengan menggugurkan 9 butir item yang tidak valid, terjadi peningkatan koefisien reliabilitas cronbach's alpha dari 0,848 menjadi 0,930 dengan mengurangi butir item dari 60 menjadi 51. Selanjutnya digugurkan item nomor 9, 45 dan 55.

Analisis Ketiga, hasil uji ulang dengan menggugurkan 3 butir item yang tidak valid, ternyata terjadi peningkatan koefisien reliabilitas cronbach's alpha dari 0,930 menjadi 0,959 dengan mengurangi butir item dari 51 menjadi 48. Pada tabel Corrected Item-Total Correlation, seluruh butir telah memiliki koefisien korelasi butir terhadap total yang sama atau lebih besar dari 0,3. Artinya seluruh butir telah memberikan sumbangan terhadap totalnya $\geq 30 \%$. Setelah diperoleh 48 butir yang memiliki sumbangan $\geq 30 \%$ terhadap skor total, maka tahap berikutnya adalah merevisi instrumen.

\section{Revisi Produk Operasional}

Berdasarkan hasil uji coba kepada 10 konselor di Kabupaten Sukoharjo, peneliti melakukan analisis terhadap item instrumen yang perlu dibuang, direvisi, atau dipertahankan. Hasil analisis uji statistik instrumen kinerja konselor dalam layanan konseling untuk Self-Evaluation diperoleh bahwa terdapat 14 item yang tidak valid, yaitu item nomor 9, 23, 24, 25, 31, 34, 45, 46, 50, 51, 48, 49, 8, dan 55. Peneliti melakukan tindak lanjut analisis uji teoritik dan membuang tiga butir item instrumen, yaitu nomor 8, 24, 31, sementara item yang lain tetap dipertahankan.

Selanjutnya hasil analisis uji statistik untuk Peer-Evaluation diperoleh ada 12 item yang tidak valid, yaitu item nomor 15, 23, 24, 25, 26, 27, 31, 34, 37, 9, 45, dan 55. Peneliti melakukan analisis uji teoritik dan membuang tiga butir item instrumen, yaitu nomor 24, 31, dan 37, sementara item yang lain dipertahankan.

\section{Uji Coba dan Penyempurnaan Produk yang telah Disempurnakan}

Peneliti melakukan uji coba ke lapangan yang lebih luas yaitu kepada 20 konselor sekolah di Kabupaten Bantul. Hasil analisis instrumen dapat dijelaskan sebagai berikut.

\section{Uji Coba Instrumen Self-Evaluation}

Analisis Pertama, hasil perhitungan reliabilitas instrumen menggunakan rumus cronbach's alpha (table 5.5), diperoleh koefisien sebesar 0,717 ( $\geq 0,5)$. Selanjutnya perlu diperhatikan koefisien nilai dalam tabel item-total statistics pada kolom corrected item-total correlation. Item yang mendekati 0,3 akan dipertahankan, karena ada kemungkinan korelasinya akan meningkat setelah dilakukan analisis uji ulang. Peneliti mencoba terlebih dahulu mengeluarkan butir soal yang memiliki koefisien corrected item-total correlation pada rentang $-0, \ldots$ sampai 0,200 . Berdasarkan hasil uji validitas diperoleh 32 item dengan koefisien di bawah 0,3 yaitu nomor $2,3,5,6,7,9,10,11,12,17,19,20,22,23,25,28,29,30,32,33,34,35$, $36,38,39,40,41,43,45,46,47$, dan 51. Peneliti akan melakukan uji ulang, sehingga mengeluarkan 14 item terlebih dahulu yaitu nomor 2, 7, 9, 11, 29, 30, 34, 35, 36, 38, 39, 41, 43, dan 45 .

Analisis Kedua, hasil uji ulang dengan menggugurkan 14 butir item yang tidak valid diperoleh peningkatan koefisien reliabilitas cronbach's alpha dari 0,717 menjadi 0,887 dengan mengurangi butir item dari 57 menjadi 43. Selanjutnya digugurkan item nomor 10, 12 dan 40.

Analisis Ketiga, hasil uji ulang dengan menggugurkan 3 butir item yang tidak valid diperoleh peningkatan koefisien reliabilitas cronbach's alpha dari 0,887 menjadi 0,893 dengan mengurangi butir item dari 43 menjadi 40. Selanjutnya digugurkan item nomor 3, 6, 28, dan 32.

Analisis Keempat, hasil uji ulang dengan menggugurkan 4 butir item yang tidak valid diperoleh peningkatan koefisien reliabilitas cronbach's alpha dari 0,893 menjadi 0,902 dengan mengurangi butir item dari 40 menjadi 36. Selanjutnya digugurkan item nomor 33 dan 47.

Analisis Kelima, hasil uji ulang dengan menggugurkan 2 butir item yang tidak valid diperoleh peningkatan koefisien reliabilitas cronbach's alpha dari 0,902 menjadi 0,906 dengan mengurangi butir item dari 36 menjadi 34. Selanjutnya dicoba menggugurkan koefisien yang mendekati 0,3 yaitu item nomor 5, 23, dan 25 .

Analisis Keenam, hasil uji ulang dengan menggugurkan 3 butir item yang tidak valid diperoleh peningkatan koefisien reliabilitas cronbach's alpha dari 0,906 menjadi 0,908 dengan mengurangi butir item dari 34 menjadi 31. Pada tabel Corrected Item-Total Correlation, seluruh butir telah memiliki koefisien korelasi butir terhadap total yang sama atau lebih besar dari 0,3. Artinya seluruh butir telah memberikan sumbangan terhadap totalnya $\geq 30 \%$. Setelah diperoleh 31 butir item yang memiliki sumbangan $\geq 30 \%$ terhadap skor total, maka tahap berikutnya adalah merevisi instrumen. 


\section{Uji Coba Instrumen Peer-Evaluation}

Analisis Pertama, hasil perhitungan reliabilitas instrumen menggunakan rumus cronbach's alpha (table 5.6), diperoleh koefisien sebesar 0,851 ( $\geq 0,5)$. Selanjutnya perlu diperhatikan koefisien nilai dalam tabel item-total statistics pada kolom corrected item-total correlation. Item yang mendekati 0,3 akan dipertahankan, karena ada kemungkinan korelasinya akan meningkat setelah dilakukan analisis uji ulang. Peneliti mencoba terlebih dahulu mengeluarkan butir soal yang memiliki koefisien corrected item-total correlation pada rentang $-0, \ldots$ sampai 0,200 . Berdasarkan hasil uji validitas diperoleh 25 item dengan koefisien di bawah 0,3 yaitu nomor $2,3,6,7,8,9,10,16,22,28,29,30,32,34,35,36, .39,41,43,45,52$, 55, 56, 57, dan 59. Peneliti akan melakukan uji ulang, sehingga terlebih dahulu mengeluarkan 12 item yaitu nomor 7, 9, 10, 22, 32, 35, 36, 41, 43, 45, 52, dan 59 .

Analisis Kedua, hasil uji ulang dengan menggugurkan 12 butir item yang tidak valid diperoleh peningkatan koefisien reliabilitas cronbach's alpha dari 0,851 menjadi 0,905 dengan mengurangi butir item dari 57 menjadi 45. Selanjutnya digugurkan item nomor 2, 6, 8, 39, dan 57.

Analisis Ketiga, hasil uji ulang dengan menggugurkan 5 butir item yang tidak valid diperoleh peningkatan koefisien reliabilitas cronbach's alpha dari 0,905 menjadi 0,919 dengan mengurangi butir item dari 45 menjadi 40. Selanjutnya digugurkan item nomor 3, 28, 29, 55, 56, 58, dan 60.

Analisis Keempat, hasil uji ulang dengan menggugurkan 7 butir item yang tidak valid diperoleh peningkatan koefisien reliabilitas cronbach's alpha dari 0,919 menjadi 0,927 dengan mengurangi butir item dari 40 menjadi 33. Selanjutnya digugurkan item nomor 4, 34, dan 38.

Analisis Kelima, hasil uji ulang dengan menggugurkan 3 butir item yang tidak valid diperoleh peningkatan koefisien reliabilitas cronbach's alpha dari 0,927 menjadi 0,935 dengan mengurangi butir item dari 33 menjadi 30. Selanjutnya digugurkan item nomor 30, 40, dan 53.

Analisis Keenam, hasil uji ulang dengan menggugurkan 3 butir item yang tidak valid diperoleh peningkatan koefisien reliabilitas cronbach's alpha dari 0,935 menjadi 0,944 dengan mengurangi butir item dari 30 menjadi 27. Pada tabel Corrected Item-Total Correlation, seluruh butir telah memiliki koefisien korelasi butir terhadap total yang sama atau lebi besar dari 0,3. Artinya seluruh butir telah membrikan sumbangan terhadap totalnya $>30 \%$. Setelah diperoleh semua butir yang memiliki sumbangan $\geq 30 \%$ terhadap skor total, maka tahap berikutnya adalah merevisi instrumen.

Berdasarkan hasil uji coba kepada 20 konselor di Kabupaten Bantul, peneliti melakukan analisis terhadap item instrumen yang perlu dibuang, direvisi, atau dipertahankan. Hasil analisis uji statistik instrumen kinerja konselor dalam layanan konseling untuk Self-Evaluation diperoleh bahwa terdapat 26 item yang tidak valid, yaitu item nomor 2, 7, 9, 11, 29, 30, 34, 35, 36, 38, 39, 41, 43, 45, 10, 12, 40, 3, 6, 28, 32, 33, 47, 5, 23, dan 25. Peneliti melakukan tindak lanjut analisis uji teoritik dan membuang enam butir item instrumen, yaitu nomor 2, 7, 28, 29, 30 dan 31, sementara item yang lain tetap dipertahankan.

Selanjutnya hasil analisis uji statistik untuk Peer-Evaluation diperoleh ada 30 item yang tidak valid, yaitu item nomor 7, 9, 10, 22, 32, 35, 36, 41, 43, 45, 52, 59, 2, 6, 8, 39, 57, 3, 28, 29, 55, 56, 58, 60, 4, 34, 38, 30, 40, dan 53. Peneliti melakukan analisis uji teoritik dan membuang tujuh butir item instrumen, yaitu nomor $7,8,22,28,29,32$ dan 56, sementara item yang lain dipertahankan.

\section{KESIMPULAN DAN SARAN}

Sesuai hasil uji coba kepada ahli bimbingan dan konseling, dapat disimpulkan bahwa instrumen kinerja konselor dalam layanan konseling baik self evaluation maupun peer evaluation tepat, layak, dan bermanfaat untuk mengetahui kinerja konselor dalam layanan konseling individual. Uji coba terbatas instrumen self evaluation kepada 10 konselor SMP di Kota Sukoharjo diperoleh 57 butir item yang dapat digunakan untuk dilakukan uji coba pada lapangan yang lebih luas. Selanjutnya uji coba lapangan yang lebih luas instrumen self evaluation diperoleh 51 item yang dapat digunakan untuk mengetahui kinerja konselor dalam layanan konseling individual. Uji coba terbatas instrumen peer evaluation kepada 20 konselor SMP di Kota Yogyakarta diperoleh 57 butir item yang dapat digunakan untuk dilakukan uji coba pada lapangan yang lebih luas. Selanjutnya uji coba lapangan yang lebih luas instrumen peer evaluation diperoleh 50 item yang dapat digunakan untuk mengetahui kinerja konselor dalam layanan konseling individual.

\section{DAFTAR PUSTAKA}

Asep, J.(2007). Evaluasi Pembelajaran. Yogyakarta: Multi Press.

Asosiasi Bimbingan dan Konseling Indonesia. (2007). Penataan Pendidikan Profesional Konselor dan Layanan Bimbingan dan Konseling dalam Jalur Pendidikan Formal (Naskah Akademik). Bandung: ABKIN.

Atmoko. (2012). Bahan Ajar Matakuliah Desain dan Analisis Data. Malang: Universitas Negeri Malang Program Pascasarjana.

Borg \& Gall. (1983). Educational Research: an introduction fourth edition. New York: Longman.

Borg \& Gall. (1989). Educational Research: an introduction fifth edition. New York: Longman. 
Chaplin, J.P. (2006). Kamus Lengkap Psikologi, (Alih bahasa: Kartini Kartono). Jakarta: Raja Grafindo Persada.

Corey, G. (2009). Theory and Practice of Counseling and Psychotheraphy eight edition. USA: International Thomson Publishing.

Djaali dan Pudji, M. (2008). Pengukuran dalam Bidang Pendidikan. Jakarta: Grasindo.

Geldard, K., \& Geldard, D. (2012). Konseling Anak-Anak: Sebuah Pengantar Praktis-Edisi Ketiga. Jakarta: Indeks.

Hadjar, I. (1996). Dasar-Dasar Metodologi Penelitian Kuantitatif dalam Pendidikan. Jakarta: Raja Grafindo Persada.

Huda, M. (2013), (Online), (http://www.p4tkpenjasbk.or.id/index.php? option= com_content \&view=article\&id=1252:menyoal-kinerja-profesional-guru-bimbingan-dan konseling \&catid=25: artikel\&Itemid=454), diakses 7 Desember 2013.

Iskandar. (2008). Metodologi Penelitian Kualitatif. Surakarta: UNS Press.

Joy, R.M., Hesson, J.B., \& Harris, G.E. (2011). Preservice Teacher Perceptions of School Counsellor Responsibilities. Canadian Journal of Counselling and Psychotherapy, 45 (4): 386-405.

Kozlowski, K.A. (2013). Integrating School Counseling Core Curriculum into Academic Curriculum. Journal of School Counseling, 11 (5): 1-35.

Morrison, Dee Hann. (2011). The Varied Roles of School Counselors in Rural Settings. Georgia School Counselors Association Journal, 18 (1): 26-33.

Munro, Hope. (2007). The Implications of Teacher Perceptions of Career Guidance Programs and the Impact on Student Career Decisions. Georgia School Counselors Association Journal, 14: 6-13.

Olguin, D.L. \& Keim, J. (2009). Using Stakeholders as Career Bridges to Advance Students' Academic Performance: How Would You Like Your Stake?. Journal of School Counseling, 7 (22): 1-22.

Rahardjo, S. \& Gudnanto. (2013). Pemahaman Individu Teknik Nontes. Jakarta: Kencana Prenadamedia Group.

Sherwood, Heather. (2010). Utilizing Staff Perceptions to Guide and Shape Future Program Planning. Georgia School Counselors Association Journal, 17 (1): 15-25.

Sugiyono. (2010). Metode Penelitian Pendidikan: Pendekatan Kuantitatif, Kualitatif, dan R \& D. Bandung: Alfabeta.

Suharsimi dan Jabar, C.S.A. (2008). Evaluasi Program Pendidikan. Jakarta: PT. Bumi Aksara.

Suharsimi. (2010). Dasar-Dasar Evaluasi Pendidikan. Jakarta: PT Bumi Aksara.

Suryabrata, S. (2008). Metodologi Penelitian. Jakarta: Raja Grafindo Persada.

Tague-Sutclife, J.M. (1996). Some Perspective on the Evaluation of Information Retrieval System. Journal of the American Society for Information Science, 47 (1) : 1-3.

Umar, H. (2002). Evaluasi Kinerja Perusahaan. Jakarta: Gramedia Pustaka Utama.

Undang-Undang Nomor 20 Tahun 2003, (Online), (www.kemenag.go.id) diakses 7 Desember 2014. 